\title{
THE TEA ROAD: FROM CHINA TO UZBEKISTAN (7-15TH CENTURIES)
}

\author{
Mahfuza Bahriddinovna Mamatova \\ PhD Student, Karshi state university, Karshi, Uzbekistan. \\ E-mail: maxfuzamamatova@gmail.com
}

\begin{abstract}
:
Five thousand years ago, the first tea was made in China. Only from the beginning of the Middle Ages people of neighboring countries of China recognized tea and until the Tang Dynasty, tea drinking was not widespread. Beginning of the 7th century tea brought Central Asia with the Tea Road. From this period he stretched from China to India. At the centre of this path was Central Asia, the ancient cities of Uzbekistan namely after Samarkand, Bukhara, Tashkent and the Ferghana Valley. It was the northeastern Tea Road that connected China with Central Asia and was much more ancient than other directions of this route.

In the 7-15th centuries The Tea Road developed in different historical periods. During the Tang Dynasty in China, Sogdian merchants brought tea to Central Asia. During the Song Dynasty, it was traded by Central Asian merchants and opened their tea shops in China. The Samanid rulers were the patrons of the tea trade. Under the Ming and Timuridsempire, an intensive ambassadorial-diplomatic relationship between China and Central Asia was strengthened. During this period, among the various goods, the main article of Chinese exports was tea, which was exchanged for thoroughbred horses brought from Central Asia.

Since the time of the Tang Dynasty, bilateral trade has been established with Central Asia, and as part of the Tea Road, there were several main and a number of experimental routes along which tea went to Central Asia. In these paths, there were customs points - cities that played an important role in China's trade and economic ties with Central Asia.

Today, tea is considered a favourite drink of the peoples of Central Asia, including Uzbekistan. Green tea is imported to Uzbekistan from China and it has become a national drink for the people of Uzbekistan.
\end{abstract}

Keywords:

historical periods, neighboring, economic ties, tradition of drinking, ethkan.

Article Received: 18 October 2020, Revised: 3 November 2020, Accepted: 24 December 2020

\section{INTRODUCTION}

Tea has been a favorite drink of all the peoples of Central Asia from the Middle Ages to the present day. It was imported into Central Asia from China and India and it was a widespread and popular drink among the population of this region. However, there is no reliable information about when and for how long tea is consumed by Central Asians.

From sources, it is known that the road along which tea was transported was called the "Tea Road". It stretched from China to India, and in the centre of this tea path was Central Asia, namely the ancient cities of Uzbekistan: Samarkand, Bukhara, Tashkent and the Ferghana Valley. In this article, we will consider the tea route from China to Uzbekistan and its genesis in different historical periods.

Studying the tea path that went from China to India, you can divide it into three main roads: northeastern, southern and northern. The northeastern Tea Road connected China with Central Asia and was much more ancient than other directions of this route. The famous sinologist DrAblatKhodjaev writes: "At the beginning and $\mathrm{BC}$ tea was known only in China, but the Chinese did not yet know how to make a drink that quenches thirst from tea leaves. Only in the 3rdcentury $\mathrm{AD}$ was made intoxicating tea from tea leaves in China and was used secretly. The tradition of drinking tea as a drink to quench thirst arose at the beginning of the 4th century. Over the next two centuries, tea extracts were widely used among the local population"[1; p. 187]. Thus, it can be argued that tea did not spread to Central Asia until the 5th century.

\section{MATERIALS AND METHODS}

The methodology for writing the article is largely based on materials from books and magazine 
articles on the tea trade in China and Central Asia. In particular, we used an interdisciplinary approach, since our sources are archaeological, geographical, sociocultural, economic and political. This article is about the history of the Tea Road from China to Central Asia.

If you study Chinese sources, they say that until the founding of the Tang Dynasty in China, tea drinking was not widespread. "People living on pastures and raising livestock did not drink tea"[2; p. 418].

In 1987, objects from the 7th-9th centuries were found in the basement of the tower of the Faminshi Buddhist Temple ("Buddhist Temple"), which is located near the second capital of ancient China, Ch'an'an (now Xi'an). It was equipment for processing, drying, roasting, packaging and brewing tea leaves. As well as gold, silver and glassware, porcelain cups glazed with unknown dyes and light yellow glass bowls. There were samples of other utensils for making tea. Most of them, especially glass teapots, were made in the Eastern Roman Empire and brought to China in the 9th century. We can say that these objects prove that tea spread to Europe by the 9th century.

Although Arab merchants began arriving in China by sea from the middle of the 7th century, most of the trade between European countries and China during this period passed through the Great Silk Road. Therefore, we can assume that the habit of drinking tea in Central Asia appeared much earlier than in European countries.

Thesourcespreservedinformationconfirmingthisve rsion.

\section{DISCUSSION}

According to sources, during the 5-8th century, tea was purchased in large quantities in China by Uyghurs and Tibetans. The sixth chapter of the medieval essay "Hearing and Vision of Feng Zhi" (Feng Zhi Wen Jianlu) says: "Every time the Uyghurs came to the palace of the Chinese emperor, they exchanged purebred horses for tea"[2; p. 348-498]. The second part of the work tells that the Uyghurs came to the palace of the Tang Dynasty, brought many horses and exchanged them for tea, which caused great concern among the Tang government. As a result, the Tang Dynasty was forced to limit the market for the sale of horses, tea, silk fabrics. The essay also says that "during the Tang period, the Uyghurs had the custom to drink tea"[2; p. 348496].

The Uyghur state, which controlled the East Turkestan section of the Great Silk Road, had the right to free trade in China thanks to its help in suppressing the An-Lushan uprising in China in 755-757. Therefore, tea exported from China along the Silk Road was at the disposal of the Uyghurs.

According to Chinese scientists, during this period, Uyghurs ate more meat and fatty foods, and tea tincture prepared with the addition of milk played an important role in digesting meat and reducing the accumulation of fat in the body [2; p. 487]. And today, Uyghurs often drink tea with milk, and in their language such tea is called "ethkan tea."

According to sources, during the Tang Dynasty, i.e. in the 7th-9th centuries, tea became one of the main export goods in China. In the first quarter of the 7th-century tea, silk, salt and horses were the basis of trade between the peoples of North China. The sale of these goods was often based on the exchange of goods between the population of different regions. In the first quarter of the 7th century, such trade relations have become more active[2; p. 347-348]. Realizing that tea trade was profitable, merchants went abroad and increased its profitability.

Under the Tang Dynasty, tea trading became so lucrative that many people of Turkestan opened tea shops in Chinese cities, especially Chang'an, and captured most of their Chinese tea exports. The state treasury has greatly benefited. Due to increased Chinese tea exports, the shortage of silk fabrics paid in exchange for imported horses has been reduced[2; p. 420]. 
Silk fabrics depicting women distributing tea were found in grave No. 187 in Astana, near the city of Turpan in East Turkestan. After careful study and analysis, Chinese scientists concluded that this fabric dates from the 7th century and belongs to the merchants who brought Chinese tea from Western countries. Based on this, they suggested that in the 7th century. It was customary to greet the guest with tea in Turpan.

In 780, tea was first taxed by producers, buyers and sellers, and in 792 a special law on tea tax was passed. This law is called the "tea law" ("chafa"). Before this, tea sales were taxdeductible. By the Tea Law, the "bewitch" system was introduced, which lists tea producers. According to this system, every 10-15 family involved in tea trading is assigned one group (bov), and if any of them violates the law, all members of the group are equally liable. At the same time, "tea markets" were created in large cities, and tea sales will be carried out only in these markets. Relations between tea producers and buyers are tightly controlled by the government. After the law was passed, tea trade revenue became the main source of replenishment of the Tang Dynasty treasury[2; p. 419-420].

Founded in Tibet in the third quarter of the 8th century, the Tubo state (Tibetan empire, 7-9th) tightened control over the Hessian corridor and trade routes through the southern part of East Turkestan. Until 849, trade between China and the Middle East and South Asia through these territories were controlled by Tibetans. At that time, trade between the West and China was carried out along the northern route through Mongolia. This road passed through the Uyghur Khanate (744-842). As a result, the role of Uyghur merchants in international trade is increasing.

One cannot but mention the Sogdian merchants and the Sogdian colonies along the Silk Road. Sogdians were born merchants. The authors of "Jiu Tang Shu" - Liu Xinju and "Xin Tang Shu" ("The New History of the Tang Dynasty") $\mathrm{Xu}$ Oyang described how Sogdians raised merchants from their sons: "When they had a son, they smeared honey in his mouth and covered his palms glue so that as he grows and grows up he makes flattering speeches and grabs the coins with his hands as tightly as if they stuck to them ... They are skilful in business, love profit and go abroad at the age of 20 years. They can be found wherever this very profit shines"[3; $198 \mathrm{~b}$, p. 5310; 4; 221 b, p. 6243-6244].

In 1970, Xian archaeologists in the village of Hejia (Xian, China), then still considered the southern suburbs, discovered two clay pots $(64 \mathrm{~cm}$ high) and one silver jug (25 cm high), they were under sediments at a depth of about $90 \mathrm{~cm}$ and 90 $\mathrm{cm}$ apart from a friend. In these three jugs, more than a thousand diverse items were stored, including silver artefacts, gems and minerals, medicines and a rare coin collection. From the list of finds in ancient Hejia, several cups for drinks from different metals can be noted[5; p. 16]. 

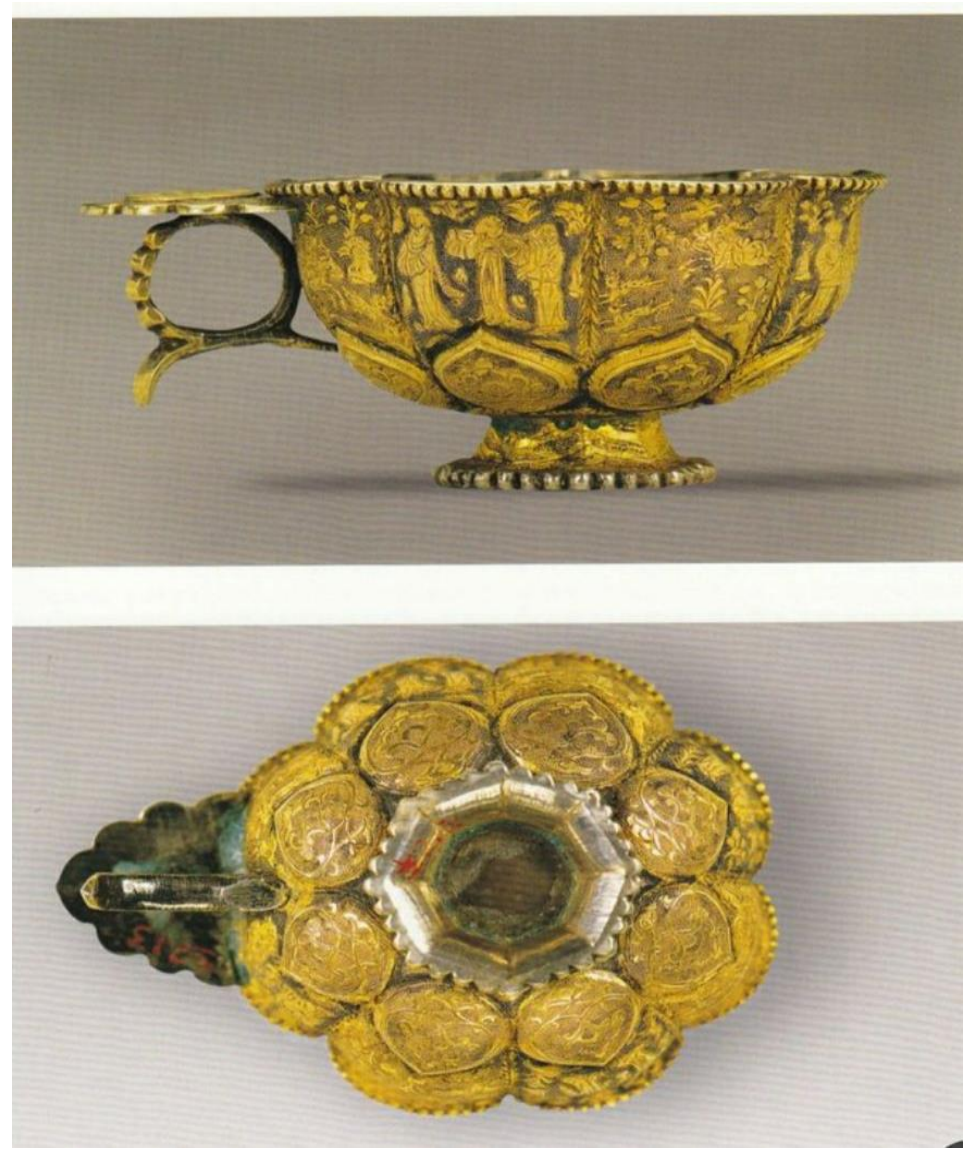

Fig.1. Sogdians' cup

The octagonal cup combines several Sogdian features: an eight-petal shape, a finish with a pearl rim and a complex thumb ring (Fig. 1). The exterior alternates scenes of horseback riding - the main element of Sasanian art, with scenes of Chinese women playing musical instruments, looking in the mirror, playing with children and dancing. Its creator was inspired by the same impulse to show the larger world that lay at the basis of his modern murals from his Sogd homeland - Samarkand. Scenes similar to the scene on the cup can be seen in one of the paintings, which depicts a Chinese emperor busy hunting, as well as a Chinese princess with her maids of honour waiting.

Manufactured by Sogdians and imported into China, these containers differ in shape from Sogdian prototypes, which were supposedly made in Chang'an by Sogdian or Chinese craftsmen [6; p. 254]. With this approach to business, it turns out that the octagonal cup looks quite definitely
Sogdian. It can be stated that the Sogdians of the 8th century drank tea from such cups and brought them for trade to China.

This period is characterized by the exchange of tea for horses. Because since ancient times, the Chinese have valued fast, well-built horses raised in the West and living outside the Great Wall. Under the Tang Dynasty, this trade developed rapidly, as traders from the west exchanged horses for tea. This barter trade influenced interstate relations and the path that this trade took was called by historians as "Chamagudao", which translates as "cha" - "tea", "ma" - horse and "tao" - "path" - "Chino- horse way ". Only this path connected Yunnan, Sichuan and Tibet. The sources also say that the people of the Tang dynasty paid a fortune for owning one of the prestigious Ferghana breeds, immortalized in the unsurpassed beauty of the statues of the fivecoloured glaze of the Tang. However, Western merchants were not interested in bills of 
exchange, as forms of payment introduced during the Tang Dynasty or paper money (jiaozi). They accepted only barter goods as payment. Brick tea used to trade with Tibet was one of the first international money, and tea was one of the goods used to pay for foreign horses. Based on this, we can name the path that connected China with Central Asia "Tea Road".

From the 10thcentury Tea has become the main export product, bringing good income to the Chinese state. It is reported that neighbours around the Chinese states exchanged one sheep for several gins of tea (1 gin weighed 597 grams, now 500 grams) [2; p. 487]. Therefore, the Northern Song Dynasty (960-1127) not only monopolized all processes associated with the cultivation and sale of tea but also registered and strictly controlled all persons involved in the tea trade [2; p. 489].

According to sources, during the Northern Song Dynasty, traders from western countries, including Central Asian, bought large quantities of tea. In China, on the other hand, due to the aggravation of the domestic political situation, the share of tea cultivation and brewing fell, and prices rose. In 1104, the price of one big horse 410 years old in China was equal to the price of 56 $\mathrm{kg}$ of high-quality tea [2; p. 495]. Therefore, the Chinese exchanged tea only for horses. The government has also taken tea trade under tight control. During the Southern Song Dynasty (11271279), horse prices rose and tea prices fell. After that, it was allowed to exchange tea not only for horses but also for other goods or sell for gold and silver coins.

During the Song Dynasty, land trade with its immediate neighbours greatly enriched China. This inter-Asian land trade was decisive in determining an important turning point in the history of tea.

On the southern border of China, the ruler of Song and Xia (Tibetans) entered into an agreement requiring an annual supply of Song of 72,000 silver, 153,000 strands of silk and 30,000 jing tea in exchange for Tibetan peace guarantees
[7; p. 278]. Trade was encouraged along the entire Northern border of the Song Empire; silk, rice, porcelain and tea were exchanged for camels, hides, sheep, wool and horses. The people of the Tang Dynasty sometimes gave a fortune for owning one of the prestigious Ferghana horse breeds.

Western merchants, the ancestors of the Turks, and Central Asian snuffers bought tea in exchange for their horses - just like the Mongols and Manchus. This trade has become so important that a government agency, the influential Horse and Tea Commission, has been created specifically to regulate it. Trade flourished over the centuries, contributing to the emergence of new varieties of tea to satisfy Western customers in China [7; p. 66-67].

After the Mongol rule of the Yuan Dynasty (1279-1368) was established in China, buying horses was no longer a problem. However, tea growing and its role in international trade are increasing.

After the fall of the Mongol Yuan Dynasty in 1368, a large centralized Ming Empire (13681644) was formed in China as a result of a powerful uprising. The military operations that accompanied the coming to power of the Ming dynasty and the subsequent struggle to strengthen it practically nullified diplomatic and trade relations between China and other countries, including Central Asia. Chinese and Central Asian sources do not contain information on trade and embassy ties between China and Central Asia for about two decades in the second half of the 14th century.

At the end of the 14thcentury restoration of relations between countries have been outlined. In 1404-1405, when Amir Timur undertook a campaign against China, the situation worsened again, but after his death, with his successors Shahrukh and Ulugbek, there was a restoration and active development of trade and diplomatic relations between the states of the Timurids and the Ming Dynasty. The rulers of both states in their messages emphasized the need to strengthen 
friendly relations, develop mutually beneficial trade and ensure the safety of trade routes.

Studying the history of Timurid-Chinese diplomatic and trade relations, questions about the organization of the Chinese customs service and caravan routes between China and Central Asia in the 15th century material from the following Chinese sources of that time can be brought in: "Ming Shu lu", "Ming shi", "Sy and guan ji", "Shuyuzhoutsylu", "Huangmingxiangxilu", "Huangmingjiubiankao", "Shi Siyuji "," Ming Hui Yao "," BianTjong Kao "and others. The most fundamental and comprehensive of them is the official chronicle "Ming Shih Lu" ("Records of the events during the reign of the Minsk emperors"). Chronologically systematic information from Chinese sources make it possible to judge the intensity of the embassy exchange between the Timurids and China.

According to the "Min Shu lu," between 1368-1398. embassies from Timur arrived in China nine times. For the period 1403-1449 (the reign of the Minsk emperors Yunle, Hongxi, Xuande and Zhentong) thirty-three embassy missions from Samarkand and fourteen from Herat arrived in China. Besides, Chinese sources report that during this time China also visited three embassies from Badakhshan, two from Andkhoy, one embassy from Khojent, Andijan and Margilan [9; p. 107].

Studying the above issues, the compositions of such Central Asian authors as Hafiz-iAbru, FashihiKhawafi and AbrurazzakSamarkandi are no less important. Valuable information contains the historical, geographical and historical works of the famous Herat historian of the Timurid era Shihab adDinnaAbdallah ibn Lutfallah al-Kharavi (Khawafi), better known as Hafiz-iAbru (second half of the 14th century - 1430). Data on customs in China is placed in his historical work "Zubdat at-tavarikh" ("Cream of Chronicles"), in a story about the Timurid embassy in China (1419-1422), based on the diary of one of the members of this embassy - Giyas ad-Din nakkash (patterner). This composition is usually known as "Tarih-i HafiziAbru" - "History of Hafiz-iAbru".

In the history of relations between the Timurid state and China, three main stages can be distinguished. The first is the end of the 14th century - was a period of establishing first contacts in order to gradually expand relations, which after a break in the middle of the 14th century began to improve again. However, due to the fact that during this period the main direction of the the foreign policy of the Chinese emperors was military operations in the north and northwest against the Mongols expelled from China shortly before, as well as due to the turbulent political situation in Mogolistan, the diplomatic and trade relations between the state of Timur and China have not yet become regular. Moreover, at the end of the reign of Timur, the situation escalated and was fraught with military conflict. However, with the death of Timur, embassy relations between the parties resumed. The second period of their relationship, which lasted the first quarter of the 15th century, was characterized by the activation and expansion of ties, which became more regular and intense. For the third stage - the second quarter of the 15th century - a general tendency towards a gradual weakening of relations, their regulation and formalization is noticeable.

Central Asian ambassadors and merchants exported tea, Chinese silk, porcelain, rhubarb, musk and other goods from China. Among various goods, the main article of Chinese export was tea, which was exchanged for thoroughbred horses brought to Central Asia. This is confirmed by information from Chinese sources. "The Ming Shi" ("History of the Ming Dynasty") says: "At the beginning (of the Ming dynasty) in the east (of the country) there were markets, (where they traded) horses, in the west - tea" [11; p. 258].

During the reign of the Ming Dynasty, the issue of import of horses again fell into the hands of cattle-breeding Western peoples and states. The Ming Dynasty paid great attention to the issue of purchasing horses and raised this issue to the level 
of state policy. This influenced the formation of the strategic policy of the Ming Dynasty to seize pastures. This was facilitated by the fact that the nomads learned to drink tea and needed to import tea. The policy of the government of this period was reflected in the phrase "please the neighbours by exchanging horses for tea and thereby increasing the power of China" [2; p. 595]. All areas related to the cultivation and sale of tea were again monopolized by the state, as in the periods of Song and Tan. Tea was transported under the supervision of military units. Those who secretly exported tea and permitted it were sentenced to death [2; p. 599]. As a result, the cost of tea has increased. In 1392, 300,000 gins (currently $150,000 \mathrm{~kg}$ ) of tea were exchanged for 340 horses [2; p. 600]. Great respect was given to the ambassadors who came as gifts of horses. In the last quarter of the fourteenth century, in the western and northern border provinces of China, a high-breed horse was rated at 40-50, a middleclass horse at 30-40 and a low-class horse at 20-30 jin. In the interior of China, this price was at least 800 times more expensive. In Sichuan, the average price of a horse's head was 1800 pieces of tea $[2 ;$ p. 597]. It is clear that the government itself made huge profits from the tea trade. Of course, the price of tea often fluctuated, but the difference between the price in the border areas of China and the price in the interior was huge.

The historical chronicles of the Ming era scrupulously list Chinese goods that were in demand by foreigners. For example, in the "Reports to the Ming Emperors from Foreign and Tributary Countries" there is information about the ambassadors' requests to give them in response to the "tribute" certain Chinese goods.

Some goods manufactured in China have been banned or restricted from exporting. For example, in the 71 of the chapter of "Min YingzunShilu" ("True Records of Emperor Min Yingzun"), there is information that is the " 5 th year of Zhentong (1440) from Kumul and other places, Ambassador Toto-Bukhua (Tokto) and others arrived at the courtyard with gifts, wished to exchange taffeta for tea, tulle and other goods as a reward. Tea is a product prohibited for export outside of China. Tulle and other goods can be exchanged ... ". Chapter 113 of "True Records" provides information on the restriction on the purchase of tea: "In the 4th year of Tianshun (1473), the KumulZhongshun-wang (loyal and humble ruler) Manawendashiri and others sent Ambassador Shidalimishi and others to the court. This embassy is asking for permission to buy tulle, tea, porcelain and other goods for tea and metal tools, you can't exchange them, only with special permission you can export them outside of China" [12; p. 236].

In the 74 of the chapter of "True Records of Wuzong (1506-1522), Emperor of the Ming Dynasty" ("Ming WuzongShilu") states that in the "6th year of Zhende (1511), the KumulZhongshun-van Sultan-Bayazet (SutanBayazi) sent Ambassador Adu-Hoja and others with gifts and they illegally bought tea from the population. Imperial decree [noted] violation of state prohibitions. The law needs to reduce the reward" [12; p. 237].

Tea was one of the most desirable objects of exchange with China.It was of great importance in the daily life of nomads. The ruling dynasty of China believed that strict rules restricting the export of tea from the country were an effective measure to supervise and expand Chinese influence in Central Asia. From the point of view of Chinese officials, the tea policy pursued provided control over the "barbarians" better than tens of thousands of well-armed warriors $[13 ; \mathrm{p}$. 234-250].

The Code of Laws of the Ming Dynasty contains the following information about the goods included in the article that were allowed for purchase by ambassadors and merchants who arrived in the capital. About the embassy from Kumul, who visited the capital, it was said that each person was allowed to buy: "tea - 50 jinn (about $0.5 \mathrm{~kg}$ ), “ qinghua "porcelain - 50 pieces, a copper-tin vessel for soup - pieces, fine silk ( gas) of each colour of 15 pieces, tulle (taffeta) - 30 
pieces, 3 weaving shuttles, hand-woven fabric - 30 pieces, cotton - 30 jin, coloured carpet - 2 pieces, paper horses (with a bodysuit image) - 300 sheets, dyes - 5 jins, fruits, granulated sugar, dry ginger, each contains 30 jin, medicines - 30 jin, plum mumé - 30 jin, black and white alum - 10 jin. There are many unauthorized goods. The bazaar is open for 5 days at the inn ..." [12; p. 237]. The example shows that merchants exported a huge amount of goods from China to their countries that they sold favourably, so they took even more gifts with them on their next trips, but in fact goods to exchange with the Chinese population.

Rising tea prices led to a decrease in the number of horses imported into China. In the mid15 th century, in order to increase horse imports, the Ming Dynasty was forced to allow private merchants to also participate in the tea trade.

During the Qing Dynasty, which overthrew the Ming Dynasty in China and was replaced by the Manchus, there was no need to replace tea with horses alone. After the Manchu conquest of China, it became possible to conquer countries such as Mongolia, Tibet, Qinghai and East Turkestan. They are no longer buyers of horses, but owners of horses, nursing and rearing. There was no need to keep tea trade under a state monopoly.

\section{RESULT}

Having studied the above data, we can say that since the Tang Dynasty, bilateral trade has been established with Central Asia, namely, the cities of Samarkand, Bukhara, Chacham and Ferghana exchanged ambassadorial offerings, as well as tea was brought to Central Asia.

Based on these materials, up to the 15th century, there were several basic and a number of experimental routes that included a tea in Central Asia as part of the "Tea Road".

Roads established in the V-IX century:

Road of 1A: Chang'an - Gansu - Dunhuang - to the southern edge of the Tarim - Khotan Yarkand - Kashgar basin.
Road of 1B: Chang'an - Gansu - Dunhuang - Hami (Kumul) - Turpan - Kuchu (Guizi) - Aksu (Gumo) - Kashgar.

Roads that developed in the XIV-XV century:

Road of 2A: Jiayuguan - Current sands (Liu sha) - Kumul (Hami) - Turpan - Ilibalyk Samarkand.

Road of 2B: Jiayuguan - Kumul (Hami) Turpan - Mogolistan - Tashkent - Samarkand Herat.

\section{Path-Roads:}

From Chang'an to Kashgar (Roads of 1A and B), it was used in antiquity and the Middle Ages, and Dunhuang played a special role in the relationship between Central Asia and China. Two main roads led west from Dunhuang. One road ran along the southern edge of the Tarim basin through Khotan and Yarkand, and the other went north - through Hami, TurpanKuchu (Guizi) and Aksu (Gumo). From Kashgar, trade caravans followed to Ferghana and Bactria, from there to India and Parthia and further to the Mediterranean [14; p. 245].

An embassy was sent from Road of 2A to Samarkand to the court of Amir Timur from China in 1395, led by Fu An. It went together with the Timur embassy returning from China to Samarkand. They proceeded through the Jiayuguan border outpost, passing 888 li (1 li $576 \mathrm{~m}$ ), crossed the Current Sands (Liusha) and after 2000 li arrived in Hami. After another 1,300 li, they reached Turpan (Tulufan). Then they arrived in Ilibalyk (Ilibali) and, having passed another 3,000 li, in Samarkand (Samaerkhan) [9; p. 110].

In 1414, bypassing Jiayuguan, the Chinese ambassador Chen Cheng proceeded to Central Asia. The purpose of this diplomatic mission was to visit the courtyard of Shahrukh in Herat. The embassy also visited seventeen other possessions of Central Asia and East Turkestan, among them Hami, Lukchun, Karakhoja, Turfan, Beshbalyk, Sairam, Angi, Tashkent, Shahrukhiya, Samarkand, Kesh, Bukhara, Andkhoy, Termez, Badakhshan. 
Based on the information collected during the trip, Cheng Chen wrote the composition "Shi Siyu-ji" ("Notes on the Embassy in the Western Territory"), also known as "Siyu fan goji" ("Description of the Foreign Countries of the Western Region") and "Siyu Sin Cheng Ji "(“ Travel Notes on the Western Territory "), which highlights the geographical position, customs and customs of the countries visited by him. From Chen Chen's descriptions, it turns out: "Hale (Herat) is located southwest of Samaerkhan (Samarkand), 11,100 or so from the outpost of Jiayuguan (county) Ganzhou (province) of Shaanxi ... Samaerkhan (Samarkand) is located northeast of Hale. From the outpost of Jiayuguan ... there are over 9700 li to it" [9; p. 110].

The Embassy of Shahrukh and Ulugbek came from Way 2B on August 5, 1420 (25 Rajab 823) from the city of Kumul (Hami), sultry deserts passed and only about a month later - on August 29, 1420 (19 Shaaban 823 ) approached the state borders of China of those times [9; p. 108]. It was a section of the border from where ambassadors were allowed into China.

Cities - customs points:

Customs cities existed in all sections of the Great Wall of China. The tradition of organizing customs points along the latter has been estimated for many centuries. They were built at different times and served trade, economic and military purposes. So, at the end of the 2nd century BC. On the conquered territory of Gansu right up to Dunhuang, a powerful line of fortifications was built and military and civilian settlements were founded. The territory of Gansu was divided into several administrative units and became a springboard for the further struggle for the possession of trade routes to the west.

A special role in the relations of Central Asia and China until the 14th century played the city of Dunhuang, from which the main roads led west. At this time, the Great Silk Road from the Chinese capital Chang'an led northwest through Gansu to Dunhuang, where it branched into two directions leading to Kashgar.
By the time of the Ming dynasty, Dunhuang had lost its leading role on the main path, she switched to the outpost of Jiayuguan. This city was located in the Gansu province on the Great Silk Road, connecting China with the Western countries. This area means "outpost in the mountains of Jiayu", was built under the founder of the Ming Dynasty, Emperor Hongyu (Zhu Yuanzhang, 1368-1398, the temple name of Taizu) in 1372 at the western tip of the Great Wall of China and was the border between China and the countries located to the west of it.

Giyas ad-Din calls Jiayuguan "guard" (ie, sentinel) and describes this way: "The guard consists of a strong fortress, around which a deep moat is dug, surrounded on all sides by mountains through which there is no way. The path lies only through the fortress, which is designed so that through some gates of the fortress they enter, and through others, they exit" [10; p. 580 b].

In the first half of the XV century. A system of outposts has been established along the entire northwestern border of China. In 1405, due to the threat of invasion by Timur's troops, the protection of the north-western borders were strengthened, the military garrisons in Gansu and Ningxia were equipped with "powder weapons", additional military units were deployed to the north [11; p. 128-129].

As already mentioned, the westernmost of these fortresses was Jiayuguan, which also played the role of a customs point. When passing through Jiayuguan, foreign merchants and ambassadors travelling to China were subjected to thorough customs inspection. According to Giyas ad-Din, on this outpost, the names, numbers and external signs of people entering China were recorded in a special notebook on which they were checked upon departure [10; p. 592 a].

In all the likelihood, merchants sometimes managed, paying a high fee, to go to some of the inner cities of China. This is evidenced by the fact of the presence of customs in the city of Tungan, referred to by Giyas ad-Din. 
The largest cities in Gansu province for Jiayuguan were Suzhou and Ganzhou, fortified as border towns.

Suzhou is a the medieval city in the Gansu province of China, the modern name is Jiuquan; in the diary of Giyas ad-Din appears under the name Sukju. During the dynasties, the first city on the way to the capital of China, after passing the Jiayuguan outpost, it was this city Giyas ad-Din who called it the first Chinese-dominated border city in the Kumul direction [10; p. 580].

In fact, the main city in northwestern China at that time was not Suzhou, but the city of Ganzhou located southeast of it on the same road. The current name of this city is Zhanye, Giyas adDin calls it Kamju. At the beginning of the 7th century In the Ganzhou area, a large Turkic population lived. In the 8th century, Ganzhou territory became part of the Tibetan state $[14 ; \mathrm{p}$. 133]. It housed the residence of the ruler of the border province in the Kumul direction, whose head Giyas ad-Din calls dang-daji. We are talking about Gansu province, which was created in the 13th century since the end of the 14th century the province was also subordinate to the Shaanxi Administration. Ganzhou was a city more significant in size and amenities than Suzhou. In describing this city, Giyas ad-Din focuses on the characteristics of Buddhist monasteries, the number of which in this city alone reached ten, as well as its other attractions [10; p. 581 a].

At the beginning of the 15th century, Suzhou and Ganzhou were not only military administrative units but played an important role in China's trade and economic relations with foreign countries. Giyas ad-Din mentions the existence in Suzhou of a market of fifty gaz widths located in the very centre of the city [10; $p$. 581 a]. China with the outside world along the northwest path, which was the reason for the increasing role of Suzhou and Ganzhou as shopping centres. The fact is that, according to Chinese law, foreign merchants who arrived in China were not allowed to go inside the country beyond these cities. On this occasion, Giyas ad-
Din writes: "In the city of Gamju, the ambassadors' luggage and (pack) animals were deposited, (left here) and nukers." This order was maintained in China and later. A detailed explanation of this is found in the work of a member of the Russian-spiritual mission in Beijing 1781-1794. Ivan Orlova: "The Chinese, in receiving foreign merchants with goods caravans and envoys, always act according to their legislation specially established for that ... foreign merchants caravans with goods pass no more than 200 people across the borders into their own state, by the dry route. "To receive envoys at the borders, always observing the number of people with them, so that the envoy does not constitute a retinue of more than one hundred people ... embassies were allowed into the capital of Beijing only in the amount of no more than twenty people" [9; p. 112].

Ambassadors and merchants were obliged to leave extra people and pack animals in the city of Ganzhou and further to Beijing (Hanbalyk), the capital of the country, followed already accompanied by the Chinese.

From the diary of Giyas ad-Din Nakkash it turns out that the ambassadors who arrived in China from various states were exempted from paying duties, in addition, they were provided with free overnight accommodation, provided with necessary services and various entertainments were arranged throughout their stay in China [10; p. 380]. In all likelihood, the Central Asian merchants were well aware of the customs procedures in China and the corresponding benefits for foreign ambassadors. They skillfully used them for their own benefit, so the list of ambassadors arriving in China was made even before going to its borders. According to Giyas ad-Din, the Chinese first demanded a preliminary list from the Timurid embassy in the city of Karakhoja (the ancient city of East Turkestan), and the second time - a few days from the Chinese border $[10$; p. 579 a]. Here is what Giyas ad-Din writes: "Daji (the ruler) compiled a list of the servants of each of the ambassadors and 
received a certifying statement from them, warning them not to add extra servants, since the Chinese order is (very) strict who will allow (in this ) a lie, then has no right to self-respect" [10; p. 579 b].

Despite the measures taken, the merchants managed to identify themselves in the lists as servants of the ambassadors. Of course, the purpose of this evasion was to avoid paying customs duties and to use other benefits that extended to envoys. However, even after this, merchants who were part of the Shahrukh embassy managed to get only to the city of Ganzhou. They were not allowed into Beijing. The practise of restricting the movement of foreign merchants across the territory of the Minsk Empire ultimately led to the growth of the cities of Suzhou and Ganzhou, in which there was lively trade during this period.

\section{CONCLUSION}

Starting from the 7th century until the 15th century tea was transported to Uzbekistan through the Tea Road. During this period, the Tea Road developed as part of the Great Silk Road. This period is characterized by the fact that tea was transported as an embassy offering.

Since the Tang Dynasty, bilateral trade has been established with Central Asia, namely the cities of Samarkand, Bukhara, Chacham and Ferghana, merchants brought tea to Central Asia. Bilateral relations developed during the Song and Ming dynasty in China and during the Samanids and Timurids in Central Asia.

Based on this, the genesis of the Tea Road can be divided into three stages:

Firstly, 7-9th centuries. The Tea Road developed during the Tang Dynasty in China, Sogdian merchants played a large role in the delivery of tea.

Secondly, 9-12th centuries. The Tea Road developed during the Song Dynasty in China, Central Asian merchants opened tea shops in China and thereby brought tea to Central Asia.
Thirdly, 14-15th centuries. The Tea Road developed during the Ming Dynasty in China and during the era of Timur and Timurids in Central Asia. During this period, Timurid-Chinese relations developed with numerous embassy exchanges, and tea was the main article of Chinese exports.

Today, tea is considered a favourite drink of the peoples of Central Asia, including Uzbekistan. Green tea is imported to Uzbekistan from China and it has become a national drink for the people of Uzbekistan.

\section{REFERENCES}

[1] Khojaev A. BuyukIpakYo'li:

munosabatlarvataqdirlar. - Tashkent:

“O’zbekistonMilliyEnsiklopediiasi”, 2007.

[2] Sichoujilumuoyishi (History of trade on the Silk Road). - Lanzhou, 1997.

[3] Liu Xu. Jiutangshu ("Old book of the Tang"), 198 b, p.5310;

[4] Ouyang Xiu Xin Tang shu (New history of the Tang), Beijing: ZhonghuaShuju, 1975. 221 b. p. 6243-6244.

[5] Valerie Hansen. The Hejia village hoard: a snapshot of China's Silk Road Trade. Orientations, Vol. 34, No. 2, February 2003.

[6] Valerie Hansen. The Great Silk Road. Moscow: Center polygraph, 2014.

[7] BaiShouyi. AnOutlineHistoryofChina. Beijing:ForeignLanguages Press, 1982.

[8] Evans John C. Tea in China: The history of China's national drink. USA: GreenwoodPress, 1992.

[9] BurievO., KolganovA. ObodnomuchastkeVelikogoShelkovogoputi // NasredneaziatskixtrassaxVelikogoShelkovogoputi. Ocherkiistoriilkulturi. Tashkent, 1990.

[10] Hafiz-iAbru. Zubdat at-tavarikhBaysanguri. Mss No. 5361 of the Manuscripts collection of the Abu RayhanBiruni Institute of Oriental Studies, Uzbekistan Academy of Sciences (IOS, UAS). 
[11] Bokshanin A.A. ImperatorskiiKitay v nachaleXV veka. Moscow, 1976.

[12] Xinjiang diphanlishizilyaoxuanji (Selected materials on the historiography of Xinjiang), Beijing.1987.

[13] Martinov A.S. o nektorixosobennostyaxtorgovlichayemilosh admi v epoxu Min. // Kitayisosedi v drevnosti I srednevekovye. Moscow, 1970.

[14] Malivkin A.G. IstoricheskayageografiyaSentralnoyAzii. Novosibirsk: Nauka, Sibirskoeotdeleniya, 1981. 